\title{
The Rise of Barotse Separatist Nationalism in Zambia: Can Its Associated Violence Be Prevented?
}

\author{
Zibani Maundeni $^{1}$, Edgar Bwalya ${ }^{1} \&$ Phana Kwerepe ${ }^{1}$ \\ ${ }^{1}$ University of Botswana, Botswana \\ Correspondence: Zibani Maundeni, University of Botswana, Botswana. E-mail: MAUNDENI@mopipi.ub.bw
}

Received: July 27, 2015 Accepted: August 31, 2015 Online Published: November 29, 2015

doi:10.5539/jpl.v8n4p263 URL: http://dx.doi.org/10.5539/jpl.v8n4p263

\begin{abstract}
This paper explores the idea that poor governance explains the rise of separatist nationalism in situations such as Zambia, Eritrea, Sudan and Somalia (in Africa) that had previously been independently governed during the colonial times, but later joined other states at independence to enjoy normal politics, but later degenerated into violent separatist nationalism. Our argument is that centralisation of power in an environment in which cultural groups are calling for regional autonomy, for even development, and for the international community to intervene on the side of peace, create grounds that explain the rise of violent separatist movements. The Barotseland Protectorate negotiated for autonomous development and, after securing constitutional guarantees in its favour, voluntarily joined Zambia in what was expected to be a one nation, two states system. After four decades of resisting constitutional amendments in favour of the centralisation of power, the Barotse of Zambia abandoned the politics of autonomous development and started calling for a separate state. Their resolve to remain peaceful is not aided by the international community that is reluctant to intervene, exposing the political process to radicals who consider violence as an alternative. The paper argues that violent separatist politics is preventable.
\end{abstract}

Keywords: separatist violence, separatist nationalism, Barotse, Zambia, international community

\section{Introduction}

How does violent separatist nationalism arise from normal politics? Can it be prevented? How can the international community help to avert political violence that separatists are likely to unleash? This essay attempts to answer these questions through an analysis of the rise of the Barotse nationalism in Zambia. The Barotse nationalism came about as a result of the joining together of the Barotseland Protectorate and the Republic of Zambia. At the end of protectorate rule (by the British)), the Barotseland Protectorate had the choice of becoming an independent state, but opted to join the Republic of Zambia and participated in its normal politics until 2012, when, after four decades calling for enhanced autonomy within Zambia, it began calling for the establishment of a separate state. We demonstrate that poor governance, or the failure to promote autonomous development of regions that demanded it, played a big role in the rise of the separatist movement in Zambia. We show how Barotse nationalism changed over the years to culminate into a peaceful separatist movement that is in the process of internationalisation.

Data for this paper were taken from public documents that have been produced in Zambia over the last 50 years. The researchers used the Barotseland Agreement 1964. Among the sources included: documents produced by Barotseland political and civil organisations in workshops, newspaper articles that contained statements by the Zambian leaders on both sides, newspaper descriptions of the events at the time they happened, letters written by Barotse leaders to the United Nations (UN), Southern Africa Development Community (SADC) heads of state and governments, and documents about International Court of Justice (ICJ) considerations of the Kosovo declaration of independence (Barotse Post, 20 August 2014). In short, the paper relied on a rich source of public material from diverse backgrounds, but mostly from Barotseland. The paper is organised as follows: the next section discusses theoretical issues that are relevant to our arguments. This is followed by a section outlining the initial Barotse nationalism as encoded in the Barotseland Agreement 1964. Then we discuss the causes of conflicts that led to the Barotse separatist nationalism. The last section discusses peaceful separatist activities and the internationalisation of the Barotse issue, as well as how neighbouring countries can help diffuse tensions and minimise violent confrontations. 


\section{Political Mismanagement of Economic, Ethnic and Racial Diversity}

Some theorists such as Beary (2008), Fisher (2012) and Mkhabela (2011)) believe that ethnic conflicts are traceable to political mismanagement, a view that we will test in this paper. This approach of political mismanagement places the state at the centre of analysis, arguing that state failure to promote the autonomous development of regions that demand it plunges many countries into constitutional crises. Beary (2008) and Fisher (2012) argue that more than four hundred years of slavery and colonialism resulted in the colonial states splitting some of the ancient African societies such as Somaliland from Somalia, and Eritrea from Ethiopia, changing the balance of power and producing amalgamations which have proved unworkable.. For example, the Barotse Kingdom was divided such that some parts of it fell under the Namibian colonial rule (formerly South West Africa), others into Bechuanaland Protectorate and the rest into Barotseland Protectorate. Such reckless divisions resulted into an unworkable political entity, exposing its peoples to incorporation into other states. In the end, post-colonial governments created systems that promoted centralisation of power in countries where autonomous development was a primary demand. The centralisation of power and the political inflexibility that prevented regional autonomy within countries led to radical internal nationalism within states and to calls for separation which sometimes resulted in violent confrontations.

The result of centralisation is that regional autonomy was suppressed, and the distribution of resources benefited some communities and marginalised others. Thus, the post-colonial governments in Africa unwittingly incited the marginalised communities to rise and to call for separation. In contrast, Fisher (2012) contends that the 2011 sub-division of Sudan into two countries illustrated that the world can sometimes find some flexibility in the unofficial rule regarding the maintenance of inherited colonial African borders. But we contend that the break-off of South Sudan can also be viewed as a failure by Sudan to promote regional autonomy for its regions, and that the split was partly due to unequal regional development which led to the south being relatively less developed compared to the north.

Other theorists such as Rothschild (1997) and Gurr and Harff (1994) contend that post-colonial conflicts in Africa and other former colonies are a result of groups of people who have or are attempting to secure more power from the central government or access to resources due to deep-rooted inequities that can be traced to colonialism and neo-colonialism. They say these conflicts, involving race, religion, ancestral lands and language, are so intractable that they are difficult to resolve or to manage. It is therefore not surprising that one of the interpretations of the causes of conflicts in Africa is that they are materialistic. For example, Saha (2007) contends that ethnic conflicts are as a result of people, including elites, being discontent with economic benefits like land, positions and jobs. He also observes that the 1990's that witnessed the third wave of democratization in Africa was blamed for fuelling ethnically based patronage networks especially during elections periods. However an argument that blames groups and communities, but absolves the state is inappropriate for analysing the Barotse issue in Zambia. The Barotse had actually negotiated for autonomous development that was never implemented. What happened instead was that the Barotse's demand for its implementation was criminalised by successive Zambian governments.

Theorists such as Nnoli (1980), Mare (1993), Irobi (2005) and Mkhabele (2011) are of the view that competition for scarce resources is a common characteristic in most African ethnic conflicts. Ethnic communities violently compete for property rights, jobs, education, language, social amenities, and health-care facilities (Irobi, 2005). These conflicts are said to be largely based on ethnicity because in the post-Cold war period there is very little variation in the ideologies among political parties. For example, according to Nnoli (1980) and Mare (1993) South Africa and Nigeria are among countries facing resource based conflicts. Some analysts such as Mkhabele (2011) argue that these types of conflicts are not only deep-rooted in the colonial past, but have also been perpetuated by post-colonial governments' failure to manage ethnic and racial diversity in the process of nation-building. They claim that the result is a politicised ethnicity which is detrimental to national unity and to economic wellbeing, and has led to ethnic wars in some countries (Irobi, 2005). But this theorising is not comparable to the case of the Barotse of Zambia who had no shared colonial history with the other peoples of that country. While Barotse lived in a protectorate, other Zambians lived in the colonial Northern Rhodesia state that later became the Republic of Zambia. In addition, Barotse's ancestral land is not known to contain any rich minerals which they may want to enjoy alone (http://www.barotseland.info/Trade.htm). Their main reason for wanting to secede from Zambia is the failure of the country's successive governments to grant them their wish and give them autonomy.

A contrasting view is held by Lake and Rothschild (1996) who contend that ethnic conflicts are a reflection of a weak state, defined as a state embroiled in ancient loyalties. They charge that in such cases state actions usually favour a particular ethnic group or region and this preferential treatment tends to fuel ethnic conflicts. Other analysts such as Barth (1969), Glazer and Moynihan (1975) and Irobi (2005), call this the instrumentalist 
approach' where it is argued that poverty and deprivation are becoming endemic, primarily due to what they term distributive injustice. Irobi observes that in the post-Cold War period, distributive injustice led to the resurgence of ethnic conflict in some societies like Rwanda, Bosnia, Sudan and Zaire. Given these circumstances, scholars such as Anderson (1991) and Irobi (2005) contend that ethnicity constitutes the most effective vehicle for survival and mobilization. In cases where groups form for economic reasons, they are known to easily disband after achieving their objectives and that this is proof that ethnicity is "a construct" rather than a constant. While there is no doubt about the underdevelopment of the Western Province of Zambia where the Barotse reside, their central issue of autonomous development is much older, starting from the constitutional negotiations and continuing after independence when they realised that the first Zambian government was violating the terms of the Barotse Agreement of 1964. In any case, the Barotse traditionalists who dominated the politics of the province opposed urbanisation that threatened their power, and were therefore not competing for property and other material things.

Lake and Rothschild (1996) argue that ethnic conflicts can be sorted out by setting-up effective governments that are capable of addressing the social issues and human needs of their people. They say the human requirements are said to include peoples' need for security and autonomy. It will become clear in the case study that the Barotse of Zambia had participated in constitutional talks and had won autonomous development at that level. It was only when the constitution was violated and their autonomy disrespected that they started calling for separation. Africa has not been lucky to have flexible governments that enforce and respect the autonomous development of the different regions of their countries. Porter (2011) contends that political mismanagement of ethnic diversity is often associated with the absence of visionary, civic-minded and nationalist leaders. But, Kenneth Kaunda was a visionary leader even though he failed the autonomous development test and plunged Zambia into secessionist politics. In other countries, such as Congo DR, Ivory Coast and Nigeria, the ethno-religious conflicts are attributed to corrupt elites that are split along religious or ethnic lines (Irobi, 2005). In the case of the Barotse of Zambia, we will demonstrate that the failure to promote the autonomous development of the region is a stronger motivation for the demand for secession.

Fisher (2012) argues that modern separatist movements are a phenomenon associated with nationalism in 19th century Europe. He notes that Woodrow Wilson's support for "self-determination" and the Russian appeals for oppressed people to 'throw-off the yoke' of imperialism fuelled the flames of these movements. In general, the demands for self-determination usually manifest themselves in the form of separatist movements, secessionist movements, or through demands for autonomy. According to Beary (2008), the post-World War II period has witnessed the increase in the number of separatist movements around the world to about 70 , and the number of affected countries has quadrupled with 26 new ones emerging after 1990. He goes on to note that in some parts of the globe, nations such as the far-flung Kurds and the Sri Lankan Tamils, have been fighting ferocious wars to establish a homeland, while others such as Canada's QuŽbŽcois appear to be content with local autonomy. There is no doubt that the Barotse of Zambia created a separatist movement, but only as a last resort, after participating in normal politics and calling for autonomous development for four decades without success.

\section{Non-threatening Barotse Nationalism (1964-2010)}

This section discusses the initial non-threatening Barotse nationalism (1964-2010). According to the Barotseland Agreement 1964, the territory known as Barotseland Protectorate, which had been governed as a separate British protectorate and had not developed politically, entered into a political union with Northern Rhodesia, to form the united Republic of Zambia in 1964. The agreement was incorporated into the Zambian constitution of 1964. Politically, the Barotseland Protectorate had a king (known as Litunga), a prime minister (known as Ngambela) and a national council. Republican nationalism did not exist in the Barotseland Protectorate. The idea that kingship could be abolished or side-lined to allow political parties and non-royal elites to rule (that is, republicanism), was weak at best. Part of the reason for this slow development of a modern political system in the protectorate was that traditional elements dominated its politics and there were no social upheavals that shook the foundations of such a system. In addition, there had been no major economic developments in the protectorate which could have revolutionised the traditionally oriented society and prepared it for republican politics. In short, Barotseland was traditionally oriented towards kingship and subsistence agriculture, and it was politically and economically backward relative to the rest of northern Rhodesia that enjoyed a modern economy based on copper mining and had trade unions and political parties. From all the available documents, the initial position of the Barotse was to seek enhanced autonomy within Zambia. Thus, its voluntary integration into Zambia meant that the country had two states. This was contrary to the slogan of Zambia's first President Kenneth Kaunda later adopted: one Zambia one nation.

It must be acknowledged that the politicians of Northern Rhodesia such as Kenneth Kaunda may have been partly tempted by the failed British-initiated federation of the two Rhodesia (Southern and Northern Rhodesia) 
and Nyasaland in the 1950s. Ironically, the black politicians of the above territories had opposed the white federation on the reasoning that it was based on a racial philosophy which undermined Africans. In short, the Northern Rhodesia politicians were already familiar with federation politics, and no sooner they entered into such an arrangement with Barotseland than they started marginalising the latter and criminalising their politics and institutions. In addition, nothing in the existing documents indicates that the Barotse themselves had any intention of initiating such a union with Northern Rhodesia or with any other territory. This may suggest that left to themselves, the Barotse of Barotseland Protectorate would have pursued independence without unity with any other territory.

However, when the idea of a union was presented, the overwhelming majority of pre-dominantly traditional Barotse people preferred inclusion within Zambia. This was particularly true of the youth who pushed for federation with Northern Rhodesia. In short, the idea of one Zambia, two states or two systems, sounded attractive to the majority of the Barotse. The youths may have anticipated that inclusion within Zambia would help modernise their traditionally oriented political system and usher it into republicanism. It later emerged that the core of the Barotseland political system would oppose any serious modernisation schemes by the central government of Zambia, something that turned President Kaunda into an authoritarian, and Barotse into 'separatists'. The differential social, political and economic development between traditional Barotseland and colonial Northern Rhodesia (with a mining based economy that had strong trade unions) were bound to create uneven development and carried within it potentials for political tensions. A less modernised Barotseland compared to the rest of Zambia had the potential to ignite nationalism arising from uneven development and marginalisation. Had Barotseland been economically and politically modernising (at the same pace as Northern Rhodesia), this was likely to have incited resistance from the traditional elements, who would have complained about the undermining and marginalisation of traditional institutions. Either way, unity with Northern Rhodesia would not have been easy.

With the above comments in mind, we now explore the Barotseland Agreement 1964, to establish what it had to offer. Our argument is that it offered a two system that was later subverted. To begin with the Barotseland Agreement 1964 partly provided as follows:

Whereas it is proposed that Northern Rhodesia shall become an independent sovereign republic to be known as the Republic of Zambia; and whereas it is the wish of the Government of Northern Rhodesia and of the Litunga of Barotseland, his Council and the Chiefs and people of Barotseland that Northern Rhodesia should proceed to independence as one country and that all its peoples should be one nation; and whereas, having regard to the fact that all treaties and other agreements subsisting between Her Majesty the Queen of the United Kingdom of Great Britain and Northern Ireland and the Litunga of Barotseland will terminate when Northern Rhodesia becomes an independent sovereign republic and Her majesty's Government in the United Kingdom will thereupon cease to have any responsibility for the government of Northern Rhodesia, including Barotseland, it is the wish of the government of Northern Rhodesia and of the Litunga of Barotseland to enter into arrangements concerning the position of Barotseland as part of the Republic of Zambia to take the place of the treaties and other arrangements hitherto subsisting between Her Majesty the Queen and the Litunga of Barotseland; and whereas on the sixteenth day of April 1964 a provisional agreement was concluded at Lusaka with this purpose and it is the desire of the government of Northern Rhodesia and the Litunga, acting after consultation with his council, to conclude a permanent agreement with this purpose (The Barotseland Agreement, 1964, p. 4.

It is evident that the representatives that entered into the Barotseland Agreement on behalf of that territory were all traditional in orientation: the Litunga, the Barotseland National Council and chiefs. In short, these were forces of re-traditionalising (that is, restoring the ancient Barotse values and practices) and resistant to modernisation (or resistant to the side-lining of traditional institutions and values, and their supplanting with professional institutions such as bureaucracies, parliaments and land boards). So, with regard to representation alone, Barotse entered into a union with Northern Rhodesia, through traditional representation and with the intention of preserving the core values and practices of the Barotse people, rather than to modernise. What this means is that Barotse successfully negotiated for One Zambia with a two state system, and that the Barotseland part of the state was to remain a monarchy within the republic.

The terms of the agreement were that: "(1) this agreement may be cited as the Barotseland Agreement 1964 and shall come into force on the day on which Northern Rhodesia, including Barotseland, becomes the independent sovereign Republic of Zambia; (2) the Constitution of the Republic of Zambia shall include the provisions agreed upon for the inclusion therein at the Constitutional Conference held in London in May 1964 relating to 
(a) The protection of human rights and fundamental freedoms of the individual;

(b) The judiciary; and

(c) The public service

It was further provided that "those provisions shown above shall have full force and effect in Barotseland" (Barotseland Agreement, 1964, p. 5). This can be read as an attempt by the republican side of Zambia to acknowledge the two systems theory, and to attempt to modernise the traditional Barotseland in a moderate way. Human rights were emphasised, the judiciary and the professional bureaucracy were to exist side by side with the traditional institutions. The fact that Barotseland agreed to such clauses implies that the traditional elements were not completely opposed to modernisation as long as their practices and institutions were not under threat. But of course, the above clauses merely extended liberal rights without directly threatening the powers of the traditional institutions. In short, modernisation left the traditional institutions intact within a competitive environment. But, as will be shown in the next section, when the Barotse started opposing the reforms that were sponsored by the state, the Zambian government became repressive, and failed to protect human rights in Barotseland.

(3) "Provision three extended equal access to the high court of the Barotse, including the requirement that high court judges were to visit Barotseland on circuit to administer justice" (Barotseland Agreement 1964).

It also provided the people of Barotseland with the right to the appeals court. But when repression visited Barotseland, all state institutions, including the judiciary, became instruments of repression.

Provision 4 addressed itself to the Litunga and his council (Barotseland Agreement, 1964, p. 6). This is the provision that directly dealt with the traditional institutions, values and practices. Section 4 (1) of the Barotseland Agreement 1964 "provided that the Government of the Republic of Zambia will accord recognition as such to the person who is for the time being the Litunga of Barotseland under the customary law of Barotseland". Section 4 (2) "provided that the Litunga of Barotseland, acting after consultation with his council as constituted for the time being under the customary law of Barotseland, shall be the principal authority for the government and administration of Barotseland". It is very clear from these two provisions that the Barotse traditional institutions were to be preserved and regarded as the main authority in that territory. This foreclosed their supplanting with authoritative republican institutions in Barotseland for the foreseeable future. These provisions ensured the two states system theory, enabling the continued existence of the Barotseland monarchy within Zambia.

Section 4 (3) conveyed powers on the traditional institutions. It reads: "the Litunga of Barotseland, acting after consultation with his council, shall be authorised and empowered to make laws for Barotseland in relation to the following matters," (Barotseland Agreement, p. 5.) that is to say -

(a) The Litungaship;

(b) The authority at present known as the Barotse Native Government (which shall hereafter be known as the Barotse Government);

(c) the authorities at present known as the Barotse Native Authorities

(d) The courts at present known as Barotse Native Courts;

(e) The status of members of the Litunga's Council

(f) Matters relating to local government;

(g) Land;

(h) Forests;

(i) Traditional and customary matters relating to Barotseland alone;

(j) Fishing;

(k) Control of hunting;

(l) Game preservation;

(m) Control of bush fires;

(n) The institution at present known as the Barotse Native Treasury;

(o) The supply of beer 
(p) Reservations of trees for canoes;

(q) Local taxation and matters relating thereto; and

(r) Barotse local festivals

Thus, the agreement authorised traditional Barotse leadership to continue making laws for their territory. The provisions above meant that republicanism would not be extended to Barotseland. These are the provisions that Kaunda's government later abolished without consulting the leadership of Barotseland.

Provision 5 centred on land. Section 5 (2) provides that in particular, the Litunga of Barotseland and his Council shall continue to have the powers hitherto enjoyed by them in respect of land matters under customary law and practice. Section 5 (3) provided that the courts at present known as the Barotse Native Courts shall have original jurisdiction (to the exclusion of any other court in the Republic of Zambia) in respect of matters concerning rights over or interests in land in Barotseland to the extent that those matters are governed by the customary law of Barotseland; Section 5 (4) provides that save with the leave of the court at present known as the Saa-Sikalo Kuta, no appeal shall lie from any decision of the courts given in exercise of the jurisdiction referred to in paragraph (3) of this article to the High Court of the Republic of Zambia.

Section 6 centred on the civil service, providing that all public officers of the Government of the Republic of Zambia who may from time to time be stationed in Barotseland shall be officers serving on permanent and pensionable terms. Provision 7 centred on financial responsibility, providing that "the Government of the Republic of Zambia shall have the same general responsibility for providing support for the administration and economic development of Barotseland as it has for other parts of the Republic and shall ensure that, in the discharge of this responsibility, Barotseland is treated fairly and equitably in relation to other parts of the Republic" (Barotseland Agreement, 1964, p. 6).

Provision 9 on interpretations, provided that "any question concerning the interpretation of this Agreement may be referred by the Government of the Republic of Zambia to the High Court of the Republic for consideration (in which case the opinion thereon of the Court shall be communicated to that Government and to the Litunga of Barotseland and his Council, acting after consultation with his Council), so requests" (Barotseland Agreement, 1964, p. 7). Provision 10 on revocation, provides that "the hereinbefore-recited Agreement of the sixteenth day of April 1964 is hereby revoked" (ibid.). The Agreement was signed by the Prime Minister of Northern Rhodesia, the Litunga, and Her Majesty's Principal Secretary of State for Commonwealth Relations and the Colonies. It was witnessed by the Governor of Northern Rhodesia, the Ngambela of Barotseland and the parliamentary Under Secretary of state for Commonwealth Relations and the Colonies.

So, except for provisions 1, 2 and 3, the rest of the Barotseland Agreement was centred on preserving the Barotseland monarchy (sometimes giving its institutions new names) and its powers, emphasising that land remained in the hands of the monarchy, that financial responsibility lay with the central government, and that interpretation of the Agreement lies with the High Court of Zambia that was authorised to give an opinion. In a sense, the Barotseland Agreement 1964 sought to preserve the Barotseland monarchy while uniting it with republican Northern Rhodesia.

\section{Practical Politics: Conflicts and Disappointments}

According to Barotse activists and leaders, the Zambian government never respected the Barotseland Agreement 1964. In what they term 'The abrogation of the Barotseland Agreement 1964', they cite a number of instances that confirm their observation that successive Zambian governments never intended to implement the agreement. They cite (1) the Local Government Act No. 69 of 1965 which repealed the Barotseland Native Authority Ordinance (http://www.parliament.gov.zm). Section 113 of the Act states that: "the provisions of this Act shall apply in Barotseland and the powers contained herein may be exercised in relation to Barotseland notwithstanding anything to the contrary contained in any other written law or in the Barotseland Agreement 1964" (http://www.parliament.gov.zm). So, immediately after the Barotseland Agreement was approved and signed, by 1965 the Zambian government and Parliament had already started reversing it.

Barotse leaders and activists also cite the Local Courts Act No. 20 of 1966 (http://www.zamlii.org/zm/legislation/consolidated-act/2). They say "the Act repealed the Barotse Native Courts Ordinance, thus contravening the Barotseland Agreement of 1964 because the powers of the Litunga exercised in relation to the establishment of Courts in Barotseland were provided for in Section 40 of the 
Ordinance". They further cite the Constitution of Zambia (Amendment) Act No. 69 of 1969, which provided that: - "The Barotseland Agreement 1964 shall cease to have effect and all rights (whether vested or otherwise) and liabilities thereon shall lapse". So in a sense, one party to the Barotseland Agreement was unilaterally abolishing it without the consent of the other party. This was one example of poor governance on the side of the Zambian government, and the beginning of conflict.

Finally, Barotse leaders and activists cite the Western Province (land and Miscellaneous Provisions) Act No. 47 of 1970, which they claim: "[...]took away powers vested in the Litunga of Barotseland by various enactments such as Fisheries, Forestry, Wildlife and National Parks, fauna, appeals by Local Courts to the Saa-Sikalo in matters related to the land. Worst of all, it deprived the Litunga of the rights to land which was previously vested in him and thereafter the land became vested in the President of Zambia". All these actions by the Zambian government alienated the Barotse people, who decided to constitute a significant opposition against Kenneth Kaunda's United National Independence Party (UNIP) government. In the 1969 elections, UNIP lost all but two of its seats in Barotseland, prompting Kaunda's government to initiate reforms that established a one party state that further reversed the Barotseland Agreement 1964. Thus, responding politically by constituting an opposition to Kaunda's rule and ensuring that his UNIP party lost parliamentary seats in the Western Province only helped President Kaunda to change the rules of the game. A one party state was declared, outlawing any political opposition, and thus, closing an important forum and closing out Barotse from participating in national politics. At this point the Barotse were not calling for separation. Rather, they actively participated in the politics of Zambia and opposed the nullification of the 1964 agreement.

Barotse leaders and activists further claim that successive Zambian governments ruled Barotseland with intimidation and violence, amid protests and calls for the restoration of the Barotseland Agreement 1964. Zambia was ruled through a state of Emergency and by one party, making it difficult for the Barotse to organise politically against the violations of Barotseland Agreement 1964. For instance, in a document outlining the development of Barotse politics, it is noted that successive Zambian governments illegally administered and controlled Barotseland by intimidation and force since October 24, 1964, despite continued protests from the people of Barotseland against such transgressions, including futile calls to restore the agreement. It is this intimidation and force that gave rise to Barotse separatist nationalism.

Uneven development, according to the Central Statistics Office of Zambia (CSO, 2011) is demonstrated by the fact that the "Western Province is the poorest among all the nine provinces of Zambia and therefore the least developed region in the country" (page6). This is due to the uneven sharing of resources, particularly the lack of tertiary education institutions in the province. In addition, the Zambian Educational Statistics Bulletin of 2009 showed that the Western Province lagged behind in educational infrastructure, with the least number of secondary schools (36) compared to other provinces that had over 100 schools each. The Barotse activists also claim that enrolments are very low in the Western Province. The observation of uneven development is clearly captured in the following statement: "aware that successive Zambian governments continue to undermine the modernisation of Barotseland institutions and governance required to run an independent modern state as well as meddle in the national affairs of Barotseland, resulting in conflict in some sections of the Barotseland nation (Barotse Post, 30 October, 2013). Their blame on successive Zambian governments for the underdevelopment of the Barotse province. But we acknowledge that a part of any country that was deeply involved in protests and demonstrations on the one hand, and intimidation and the use of force on the other hand, was unlikely to have had orderly development.

Barotse activists also assert that the overwhelming majority of Barotse voters in 2011, voted for Michael Sata's Patriotic Front (PF) because he had promised to respect and implement the Barotseland Agreement 1964. Sata is accused of reneging on the promises he made during his electoral campaigns. He had promised that 'The Barotseland Agreement was still valid and must be honoured'; that 'his PF government, [if] voted into power, would honour the agreement without hesitation because they have no problem with it'; that 'Zambians needed to learn to live in a country of diversity and that it was a fundamental principle even in the international law for successive governments to honour agreements they found since the agreement was not about secession but a higher and advance form of national unity'; that 'the agreement could not be treasonable because the peace and unity that Zambia has enjoyed since independence as a sovereign state could be partly attributed to the Barotseland Agreement'; and the 'PF would like to see to it that Zambia remained an oasis of peace by engaging the people of Barotseland over the Barotse Agreement to ensure that their grievances are solved once and for all' (Chellah, 2011 p30). Barotse activists and leaders allege that these positive statements convinced the overwhelming majority of Barotse voters to vote for Sata's PF that 
won the presidential elections in 2011.

Once elected into office, Sata changed his mind on the Barotse question, insisting that his duty was to respect the Zambian constitution that had side-lined the Barotse Agreement 1964 (Lusaka Times, 25 February 2012; London Evening Post, 24 February 2012). It was this politics of deception that finally convinced Barotse that separatism was an option to be seriously explored. Barotse activists no longer wanted to trust any Zambian government.

\section{Separatist Activities: Violence and Security Threats}

Separatist tendencies have dominated the politics of Barotseland since 2010. Barotse activists have been scanning international literature for precedents, and they use judgements of the International Court of Justice when it was called to determine the status of Kosovo, ruling that there is no international law that prohibits the separation of any part of any country if the conditions that brought the 'unitary' arrangements have failed to work.. One Daniel Bethlehem QC, Legal Advisor to the Foreign and Commonwealth Office is quoted in the Kosovo decision, saying:

Serbia by initiating proceedings before the ICJ wants to set back the clock, and seeks an advisory opinion that would compel Kosovo to re-engage with Serbia over its status. There is, however, no reason whatsoever to believe that an agreed outcome would be any more achievable now than it was in the past. The United Kingdom warns about the misleading approach of Serbia, which would like the court to assess the legality of the declaration, ignoring the events that led to it. Serbia has made it quite clear that it will never accept an independent Kosovo. Kosovo for its part has made it quite clear that given the legacy of abuse, it cannot again become part of Serbia. Courts do not order estranged spouses to continue in a broken marriage. Although the resolution 1244 referred to the territorial integrity of Yugoslavia, this principle was not the cornerstone for a political solution of Kosovo's status. The United Kingdom did not come to support independence for Kosovo quickly or easily and does not see these proceedings as adversarial to Serbia. Serbia's democracy is not much older than Kosovo's. Independence of Kosovo brought stability to the region after a traumatic decade. The common future for both Kosovo and Serbia lies in eventual membership for both states in the European Union and the United Kingdom will continue to work towards the realisation of that vision (22 July 2010).

Such an important legal opinion has emboldened the Barotse leaders to believe that an amicable separation from Zambia is legally possible. They are convinced that international law is on their side and have been pushing and preparing for legal battle if it comes.

There is also a parallel process of agitation and rioting. The Western Province (Barotseland) experienced riots in January 2011; 2013 (Socialist Standard, March 2011, Barotseland Post, April 2013). Explanations of the riots centre on the activities of the Zambian National Constitutional Conference (NCC) which chose to ignore submissions by the Barotse and the subsequent attempt to suppress them.

In spite of spirited submissions by the people of Barotseland and the Barotse Royal Establishment to the National Constitutional Conference (NCC) for the new constitution to recognise the Barotseland Agreement 1964, the Draft Constitution that was finally presented for enactment into the Constitution of Zambia 2010 contains draconian provisions which seek to criminalise any further efforts by citizens to engage in advocacy work seeking the reinstatement of the Barotseland Agreement 1964. To illustrate this point an extract of the Draft Constitution, being Part II thereof, circulated by the NCC secretariat for public scrutiny and comments in June 2010 is attached herewith as Appendix I. It will be noted that Articles 4.2, 4.3 and 4.5 of the proposed constitution are specifically targeted at the people of Barotseland and are designed to supress and criminalise any future effort by proponents of the Barotseland Agreement 1964 to have the matter revisited by the Government of Zambia (Geloo, 2012: 5).

Thus, the impression given by the separatists is that the rioting was not part of their agenda which primarily focused on peaceful processes. In response to the draft constitution, Barotse pressure groups formed an umbrella organisation called the Movement for the Restoration of the Barotseland Agreement (MOREBA) that subsequently (i) embarked on an awareness campaign meant to produce a coordinated mass rejection of the Draft Constitution and (ii) made the issue an electoral matter by encouraging voters to reject Barotse politicians and political parties that did not support the restoration of the Agreement.

The fact that Barotse submissions to the Draft Constitution were rejected explains the start of separatism and the rioting that followed. What is also emerging is that MOREBA's campaign led to more groups being 
brought on board such as the radical Barotse Freedom Movement and the Linyungandambo that started spearheading a separatist agenda. The fact that separatism united the different Barotse pressure groups suggests that their activities may get more coordinated, effective, sustained and radicalised. When public meetings were called and the police, who were notified, banned the meetings in October 2010, this prepared the ground for riots in January 2011 when the police disrupted planned mass meetings (Geloo, 2012).

In contrast, the early responses of the Zambian authorities indicate their readiness to use force to deal with the activists, including the banning of meetings, mass arrests, detentions and the use of lethal force. In the process 19 people got killed (Barotse Post, 24 April 2013). This prompted the Zambian authorities to adopt measured and restrained interventions by allowing meetings to be conducted with close monitoring. In December 2011, President Sata met the Barotse leadership at the state house in Lusaka (Barotse Post, 24 April 2013). This was a clear sign that President Sata was moving away from violent confrontations and preferring dialogue over violence. However, he wanted to discuss the restoration of the Barotseland Agreement at a time when Barotse groups wanted to discuss Barotseland's break away from Zambia. But the fact that they met and talked was a sign that they were avoiding the escalation of violence.

Subsequently, scheduled meetings among Barotse pressure groups were successfully held without police interference. For instance, a meeting organised by representatives of MOREBA in March 2012, and attended by sub-committees of the Barotse National Council, was concluded successfully, with a number of separatist resolutions passed. It was at that meeting that a document titled "Foundation Document Constitution of Barotseland - Barotseland's Emancipation Act and Restoration Order 2012" was discussed and launched (Barotse Post, 15 August 2012). The Zambian police who were aware of the meeting allowed it to go on, and only picked two people (General Masheke and Wanga) from it for questioning. In short, an important separatist meeting was allowed to go on without police intervention, thus avoiding possible riots and preventing the outflow of refugees.

Another meeting organised by the Barotse National Council (BNC) at St. Lawrence hall in March 2012 concluded successfully without any disruptions (Barotse Post, 24 April 2013). It made far reaching resolutions: it appealed for peace and calm; emphasised its readiness not to take kindly to any individual, authority or groups bringing the institution of the Litungaship into public ridicule (President Sata was its target as he had made remarks about the Litunga); asked the Government of Zambia to stop its officers from committing violence and intimidation against Barotse; and warned that it would formalise a 'Declaration of Dispute' with the Zambian Government that it accused of systematic violation of the Barotseland Agreement 1964; it further resolved to approach SADC governments and the UN about Barotseland's intention to secede from Zambia. The question that is relevant but will be discussed later is whether when approached to support dialogue between the warring parties, the regional and international communities would not intervene, out of respect for Zambian sovereignty.

Yet another peaceful meeting of the Barotseland National Council (BNC) was successfully held on the $16^{\text {th }}$ April 2012, passing some more radical resolutions. It sought the intervention of the UN Secretary General (letters were dispatched and meetings scheduled); rejected the continued oppression of Barotse by the Zambian government; demanded that the Litunga, King of Barotseland be accorded diplomatic immunity according to the convention of the privileges and immunities of the United Nations; demanded that the Ngambela, the Prime Minister of Barotseland, be accorded similar diplomatic immunities; demanded that Zambian soldiers be withdrawn from Barotseland under the supervision of NATO; requested that Barotseland be recognised as an independent state; requested that the laws of Barotseland be respected; pleaded that NATO should help them locate mass graves; and that the UN should protect and train the security personnel of Barotseland. It is clear that the Barotse groups want to involve the international community to help resolve the impasse.

In July 2012, the Barotseland separatists circulated a document titled "the University of Barotseland: Concept paper". Its circulation was neither interrupted nor interfered with in any way. The activists have also gone ahead and appointed a prime minister - the Ngambela, to spearhead separatist nationalism, with a clear agenda aimed at breaking away from Zambia. When addressing the Barotse National Council in March 2012, the newly appointed Ngambela observed:

I have faith in our peace loving nature and am confident that we shall forever remain committed to finding a peaceful settlement to the Barotseland Question. We are committed to non-violent means of conflict resolution. Though our blood has been spilt we will spill no innocent blood, though we have been shot we will not throw even a pebble at our aggressors, though some among us have been killed we endeavour to destroy no life, though we have been tortured and persecuted we will 
treat all persons with human dignity. Yet our peaceful nature should not be mistaken for lack of courage or determination to have this impasse resolved (Siyinda, 26 March 2012).

In June 2012, the Ngambela was also preparing to meet the religious establishment, with the intent of inviting them either to be mediators or arbitrators.

The Barotse separatists expanded their peaceful activities. For example, in October 2012, the Ngambela was touring areas within Barotseland. In addition, the Barotse Royal Establishment led by King Lubosi Imwiko II and the Barotse Ngambela (Prime Minister) Clement Wainyae Sinyinda met the British High Commissioner to Zambia John Thornton in October 2012, and informed him of their decision to secede from Zambia. Still in October 2012, the Barotseland Royal Establishment turned down an invitation to participate in a draft constitution of Zambia, and activists allegedly destroyed 500 copies of it. It is alleged that the ruling PF party activists were distributing the draft constitution which the Barotse activists confiscated and handed to the provincial authorities. The media reported that "hundreds of angry Barotseland activists invaded the District Administration Office in Mongu and tore over 500 copies of the Draft Zambian Constitution booklets translated into Lozi" (Zambia Watchdog, 7September 2012). When the authorities refused to accept the collected copies, the activists burned them. Even though the police intervened and made arrests, there was no rioting. In fact, police intervention prevented clashes between the Barotse youth activists and the ruling PF party activists. These kinds of activities had the potential to incite violence, but it was averted, a clear sign that both the Zambian authorities and Barotse activists were committed to a peaceful process. What is worrying though is that instances such as the above where rival political activists met on the streets were allowed to occur, exposing Barotseland to potential violence.

Most youth leagues of separatist movements often push their mother bodies towards radicalism and violence. Barotseland National Youth league is not expected to be different. However, so far the youth league restricted itself to writing petitions to the United Nations and to the Zambian President Michael Sata, alleging that Zambia was illegally occupying Barotseland. In the petition, the youth league wrote:

... we as Barotseland National Youth League demand that you remove your administration from Barotseland immediately and we are only giving your government twenty-one (21) days ultimatum, failure to which we shall petition the international community (United Nations) to sanction your country and government for the violation of the United Nations Security Council resolution 276 (1970), 2145 (XXI), United Nations General Assembly 1966, resolutions 264 (1969), security Council resolutions 1514 (XV) of 1060 and Security Council resolution 283 (1970). (Barotse Post, 20 October 2013.)

When the Zambian government failed to remove its administration from Barotseland, the youth league petitioned the United Nations rather than resort to violence. This also shows a commitment to the peaceful resolution of conflicts. In addition, the league indorsed the appointment of Professor Sitwala to represent Barotse interests in Southern Africa and to raise funds for legal representation from friendly countries such as Botswana.

Further, the Prime Minister of Barotseland wrote letters to the UN Secretary General, to SADC governments, to the AU (Barotse Post, 4 September 2013). His letters state that the intension was to formally declare a dispute with Zambia, and for the UN to get involved. The Barotseland National Council also wrote to a French international legal firm (Lazareff le Bars) asking it to represent the Barotse in the event that they refer their issue for international arbitration.

In addition, the $\mathrm{BNC}$ applied for membership in an international organisation called Unrepresented Nations and Peoples Organisation (UNPO) where it wanted to share its separatist agenda. The UNPO aims to make the voices of minorities to be heard and does not support violent confrontations. All these activities suggest that the Barotse intended to pursue a peaceful legal route to pursue their separation from Zambia. However, Barotse suspected that the Zambian government wanted to prevent the Ngambela from attending UNPO meetings. In addition, lack of financial resources prompted Barotse activists to approach Botswana for financial help and even asked it to allow its territory as a departure point. Botswana refused to help in both cases. Such a refusal could compromise the peaceful approach to conflict resolution adopted by the Barotse, leading to frustrations that could result in violent confrontations and a refugee problem. Indeed Professor Sitwala wrote to President Khama making that point.

We realise that on our own (Barotseland and Zambia), we'll not be able to resolve this matter - hence, our request for assistance. Parallel to these consultations, we're approaching other bodies such as the United Nations, the African Union, the Commonwealth, and others to stand with us on this journey. We're committed to a peaceful resolution of this matter through negotiations and/or courts of law. However, this, 
notwithstanding, in recent years we have had to contend with a growing number of militant young people who are growing very impatient with the BRE leadership which they see as being too soft in its approach. For this reason, we are appealing for the form of assistance that will assist us to accelerate this peaceful approach, so that we avert the possibility of violent confrontations in future. The impatience of the youth is not totally without foundation. You may know that on January 14 last year, the Zambian government slaughtered 19 unarmed youths (and maimed many more) in Mongu, as they sought to match to the king's palace to request him to reclaim his territory, as necessitated by the termination of the Barotseland Agreement 1964..." (Barotse Post, 4 September 2013).

The quotation shows that Barotse's separatist nationalism is not immune from violence, particularly if neighbouring countries and the international community refuses to intervene. In addition, refusal to aid in peaceful processes mentioned above also removed Botswana from being a player in a negotiated settlement.

\section{Involvement of Regional and International Communities}

There is no doubt that the peace process could easily collapse, particularly if the youth movement proves to be too impatient, and if the Barotse leadership has inadequate funding to see it through. In light of the above possibilities, the Barotse separatists of Zambia have approached some neighbouring countries, regional and international bodies to help aid the peace processes moving forward. They asked for the following from Botswana:

\section{Recognition from Botswana}

2. Permission to anchor the peaceful struggle of Barotseland on Botswana's soil

3. Financial assistance to pursue peaceful legal processes and to be able to attend international forums

The issue of recognition is a politically sensitive one, and individual countries choose to avoid it. Recognition of a separatist movement is best handled by bodies such as the UN and AU. There is no doubt that recognition from Botswana would have been a clear violation of the sovereignty of Zambia and of international norms.

In contrast, permission to anchor peaceful activities aimed at pursuing peaceful means seems harmless enough to have been granted under certain conditions. In addition, financial assistance to pursue peaceful processes (meeting legal bills and financing attendance of international conferences) could have been granted immediately. The fact that both the Barotseland Prime Minister and their regional contact person, Professor Sitwala, wrote separate letters to President Ian Khama, extolling the historical friendship between their former kings (Khama III and Lewanika) and peoples, and asking for civic (and not military) assistance, is evidence that Barotse were very hopeful that a principled democratic Botswana would come to their aid. According to Sitwala, the Barotse associate Botswana with the virtues of freedom, liberty and equality. These virtues were the foundations of liberation movements all over the world. Should Botswana choose not to support Barotseland in its peaceful struggle for separation from Zambia and should the peaceful processes be allowed to collapse, that would result in a large number of refugees fleeing into Botswana and the Southern Africa region. Botswana's failure to live-up to expectations could compromise its national interests in the Barotse area. This is because Botswana's tourism is based in the region bordering Zambia (Barotseland area). According to the Botswana Tourism Board (2012), Kasane, situated along Botswana's border with Zambia, is the country's top safari destination and home to the magnificent Chobe River and Chobe National Park. It is regarded as the perfect location where the Botswana safari provides visitors easy and trouble-free admission to the Chobe National Park, popular for game viewing and bird-watching. The park is home to a diversity of wildlife park just amazes the visitors (Botswana Tourism Board). Next door to the Chobe National Park are the Caprivi Strip of Namibia and Victoria Falls (also in the Barotseland) are two widely visited tourist destinations which can be reached from Kasane. Therefore, for Botswana, the Barotseland is a strategic neighbour.

In the past, the border between Botswana, Namibia and Zambia has always been marred with some controversies and disputes. First, Botswana had a dispute with Namibia over the small river islands. Second, Namibia accused Botswana of helping the violent Caprivi nationalist movement of Mishake Muyongo (apparently of Barotse origin) in his quest for the independence of the Caprivi from Namibia. Barotse people in that region of Namibia share a common ancestor with those in Barotseland in Zambia and those in Botswana in the Kasane region and those along the railway line. Back in the 1990s, the Caprivi secessionist leader sought political asylum in Botswana in October 1998 when it became known that the Namibian government was about to arrest him and his 
group of supporters. According to the Namibian Windhoek (1998) by December 1998 more than 2200 Caprivi secessionists, including some 700 from the Linyanti area alone, had fled into Botswana to escape possible persecution from the Namibian government. Namibia's Barotse chief, Boniface Mamili, fled to Botswana claiming persecution and seeking asylum. He was linked to a separatist movement in the Caprivi Strip. ${ }^{1}$

On the one hand, by refusing to extend any civic assistance to the Barotse of Zambia, Botswana was unwittingly helping to speed up the collapse of the peaceful process and the emergence of an insurgency, and indirectly exposing its tourism to danger. On the other hand, Botswana risked being accused of meddling in the politics of Zambia if it had assisted the Barotse in their peaceful struggle for separation, and therefore violating Zambia's sovereignty. Either way, Botswana is caught in a catch 22 situation. But allowing a peaceful process to collapse could lead to the emergence of an insurgency, and risk more bloodshed and give rise to a refugee crisis. After all, Botswana extended un-specified assistance to movements as far away as Southern Sudan in the past and to the neighbouring Zimbabwe's Movement for Democratic Change (MDC) during their hour of need after the 2008 elections when that country descended into chaos. Thus, the peaceful Barotseland of Zambia should have been a deserving candidate for civic assistance from Botswana. It may not be in Botswana's interest to not facilitate a dialogue between the Barotseland and the Zambian Government.

\section{Conclusion}

This paper has discussed separatist nationalism and used the Barotse of Zambia as a case study. It did so from the point of view that not all separatist groups initially demand a separate state, and that not all of them are initially violent. Some such as the Barotse of Zambia eagerly participated in normal politics, but resisted constitutional encroachments that violated the original agreement. Zambia mismanaged its constitutional and political relations with Barotseland, forcing the latter to engage in peaceful resistance and subsequently into separatism. Using the idea that poor governance is the main source of separatist politics, the paper treated Barotseland as victims rather than as natural agitators of ethnic politics. It has shown that Zambia was constituted through the Barotseland Agreement 1964 to establish a two-system consisting of the Kingdom of Barotseland and the Republican Northern Rhodesia. It has also shown that the Barotseland Agreement that secured the autonomous existence of the Barotse kingdom was incorporated into the Zambian constitution. However, successive governments ruled Zambia through a State of Emergency and through a one party state, both allowing the UNIP government of Kenneth Kaunda and those after him to engineer the abolishment of the Barotse Agreement, and sparking peaceful resistance politics.

The paper has also shown that Barotse attempted to organise protests which were easily suppressed over the years. As a result, Barotseland never enjoyed peace and suffered from gross under-development. The territory experienced successive waves of protests that were suppressed. But the determination to restore the Barotseland Agreement persevered and reached a point where it mutated into new secessionist nationalism. This is a kind of nationalism that wants Barotseland to break away from Zambia. However, it has been a peaceful nationalism that preferred a negotiated settlement of the Barotseland question.

Calls for secession have united different sectors of the Barotseland society, from the royals, to the secessionist movements, to academics, to civil society and to youth organisations. Their cooperation crystallised in the Barotse National Council that met in early 2012 and elected a prime minister, declared independence, and wrote to and approached the Zambian president, the UN, the AU, SADC governments (particularly Botswana) and all friendly governments and organisations, to register their desire to secede from Zambia. While Zambia's initial reaction was hostile and brutal, it later softened down and initiated talks. Even the UN representative met the Barotse delegation. However, President Khama of Botswana refused to meet them, and refused to extend any civic assistance to their peaceful struggle, thus contributing to the possible collapse of the peace dialogue.

We conclude by recommending that dialogue should be encouraged and supported, particularly if its failure could lead to insurgency and violence. The international community (including Khama's government) should not wait until violence erupts before getting involved, the window of peaceful negotiations does not last for ever, particularly if it fails to produce tangible results.

\section{References}

Anderson, B. (Ed). (1991). Imagined Communities: Reflection on the Origin and Spread of Nationalism (Revised

\footnotetext{
${ }^{1}$ Minorities at Risk Project, Chronology for Lozi in Zambia, 2004) available at: http://www.refworld.org/docid/469f38f71e.html [accessed 16 October 2013]
} 
Edition). London and New York: Verso.

Barotse National Youth League. (2013). Open Letter from Barotse National Youth League, to the Head of State for Zambia Mr Michael C. Sata. Barotse Post 20th October.

Barotse Post. (2012). Transitional Constitution of Barotseland, 15 August.

Barotse Post. (2013). BNYL Writes the United Nations and the World, Endorsing the New Afumba Mombotwa Led Barotseland Government and Appeal for International Intervention in Barotseland. 4 September.

Barotse Post. (2013). Resolutions of the Barotse National Council held on 27 March 2012. 24 April.

Barotse Post. (2014). BNFA Appeals to SADC to Pay Attention to Zambia's Violation of Barotse Rights - As the ACHPRs Seeks more time to Consider Barotseland's Petition. 20 August.

Barotseland Post. (2013). Former Ngambela Taken to the Police Station for What Maybe an Arrest. 30 April.

Beary, B. (2008). Separatist Movements Should Nations Have a Right to Self-Determination? Issues in Conflict and Peace Studies, 27-55.

Bethlehem, D. (2010). International Court of Justice Reports of Judgments, Advisory Opinions and Orders Accordance with International Law of the Unilateral Declaration OF Independence in Respect OF Kosovo Advisory Opinion of 22 July. Retrieved from http://www.icj-cij.org /docket/files/141/15987.pdf

Botswana Tourism Organisation Annual Report. (2012). Gaborone: Botswana TourismOrganisation.

Bowen, R. J. (1996). The Myth of Global Ethnic Conflict. Journal of Democracy, 7(4), 3-14. http://dx.doi.org/10.1353/jod.1996.0057

Bowen, R. J. (1997, January). Ethnic Conflict: Challenging the myth. Current History, 16-21.

Burton, J. (1979). Deviance, Terrorism and War: The Process of Solving Unsolved Social and Political Problems. New York: St. Martin's Press.

Burton, J. (1990). Conflict Resolution and Prevention. New York: St. Martin's Press.

Carley, P. (1996). Self-Determination: Sovereignty, Territorial Integrity, and the Right to Secession. Peace works, 7, March, p. 3.

Chang, H., \& Dodd, T. (2001). International Perspectives on Race and Ethnicity: An Annotated Bibliography. The Electronic Magazine of Multicultural Education, Spring Edition.

Chellah, G. (2011). Barotse Agreement is valid, says Sata. Post Newspaper 8 January.

Cressida, H. (2012). Identity Politics. In Z. N. Edward (Ed.), The Stanford Encyclopaedia of Philosophy (Spring Edition).

Geloo, Z. (2012). Sata's Secessionist Struggle. 15th April, Open Society Initiative for Southern Africa. Rose Bank, South Africa.

Glazer, N., \& Moynihan, P. D. (Eds.). (1975). Ethnicity and Experience. Cambridge. Mass: Harvard University Press.

Gurr, T. (1970). Why Men Rebel. Princeton, NJ: Princeton University Press.

Gurr, T., \& Harff, B. (1994). Ethnic Conflict in World Politics. San Francisco: West View Press.

Harris, J. (Ed.). (2009). The Nation in the Global Era: Conflict and Transformation. New York: Brill.

Haug, S. W. (1998). Ethnicity and Ethnically "Mixed" Identity in Belize: A study of Primary School-age Children. Anthropology and Education Quarterly, 29(1), 44-67. http://dx.doi.org/10.1525/aeq.1998.29.1.44

Horowitz, D. L. (1981). Patterns of Ethnic Separatism. Comparative Studies in Society and History, 23, 165-195. http://dx.doi.org/10.1017/S0010417500013268

Horowitz, D. L. (1985). Ethnic Groups in Conflict. Berkeley: University of California press. Retrieved from http://www.parliament.gov.zm/downloads/VOLUME\%2016.pdf

Irobi, E. G. (2005). Ethnic Conflict Management in Africa: A Comparative Case Study of Nigeria and South Africa. Colorado: Outskirts Press.

Jenne, E. (2006). National Self Determination, a Deadly Mobilizing Device. In H. Hannum, E. F. Babbitt, \& H. Hannum (Eds.), Negotiating Self- Determination. Oxford: Lexington Books.

Kaplan, S. D. (2008). Fixing Fragile States: A New Paradigm for Development. Westport CT: Praeger Security 
International.

London Evening Post. (2012). Tempers Rising in Barotseland as Sata Breaks Campaign Promise. 24 February.

Lusaka Times. (2012). MOREBA criticizes President Sata over Barotseland U-Turn, Nkoya Chief Praise him for Rejecting the Recommendations. 25 February.

Mare', G. (1993). Ethnicity and Politics in South Africa. London: Zed Press.

Max, F. (2012). The Dividing of a Continent: Africa's Separatist Problem. The Atlantic, 10 September.

Mkhabela, J. (2011, August). Kenya: From Democratic and Economic Engine to Security and Economic Crisis. The African executive, (330), 17- 23.

Mujtaba, B. G. (2013). Ethnic Diversity, Distrust and Corruption in Afghanistan: Reflections on the Creation of an Inclusive Culture. Equality, Diversity and Inclusion: An International Journal, 32(3), 245-261. http://dx.doi.org/10.1108/EDI-12-2012-0113

Newbury, C. (1998). Ethnicity and the politics of history in Rwanda. Africa Today, 45(1), 7-24.

Nnoli, O. (1980). Ethnic Politics in Nigeria. Enugu: Fourth Dimension Press.

Paterno, S. (2012). The Problems of Ethnic Conflict in South Sudan. The Sudan Tribune, 1 January day?

Porter, S. (2011). Ethnicity in Africa: A Road to Conflict or a Path to Peace? The Africa Europe Faith \& Justice Network (AEFJN), 25 July.

Rebellion in the Post-Colonial World. (2010). APSA 2010 Annual Meeting Paper Washington DC.

Rothschild, D. (1997). Managing Ethnic Conflict in Africa: Pressures and Incentives for Cooperation, Washington, DC: Brookings Press.

Rothschild, J., \& Wingfield, N. M. (2000). Return to Diversity a Political History of East Central Europe since World War II (3rd ed.). New York: Oxford University Press.

Santosh, S. C. (Ed.). (2007). The Politics of Ethnicity and National Identity. New York: Peter Lang Publishing.

Sinyinda, C. W. (2012). 'Keynote Speech Delivered by the Right Honourable Ngambela of Barotseland to the Extra Ordinary Pizo of the Barotse National Council' held at St. Lawrence Hall in Limulunga Royal Village, Mongu, 29 March.

Smith, B. B. (2010). Land, History and Separatist Conflict: The Origins of National.

Socialist Standard. (2011). Zambia: The Riots in Barotseland. March day?.

The Barotseland Agreement. (1964). Presented to Parliament by the Secretary for Commonwealth Relations by Command of her majesty - London Her Majesty's Stationery Office, May 1964 and Reproduced in Post, 31 January, 2011.

Zambia Watchdog. (2012). Barotseland Activists Tear Zambian Constitution. 7 September.

Zambia. (2010). Census of Population and Housing Preliminary Population Figures February (2011). Lusaka: Central Statistical Office.

Zambian Educational Statistics Bulletin. (2009). Lusaka: Ministry of Education, Directorate of Planning and Information.

\section{Copyrights}

Copyright for this article is retained by the author(s), with first publication rights granted to the journal.

This is an open-access article distributed under the terms and conditions of the Creative Commons Attribution license (http://creativecommons.org/licenses/by/3.0/). 